\title{
Społeczno-gospodarcze determinanty
} rozwoju pozabankowego sektora kredytów konsumenckich. Prawna analiza działalności instytucji pożyczkowych w świetle ograniczeń normatywnych.

\section{The impact of socio-economic factors on non-bank consumer loan sector' progression. Legal analysis of loan institutions' activity in the light of normative constraints}

\section{STRESZCZENIE}

Pojęcie kredytu konsumenckiego, chociaż powszechnie utożsamiane z ofertą banków jako przeważającej grupy podmiotów świadczących usługi pożyczkowe, stanowi także przedmiot działalności innych instytucji finansowych, których status prawny nie pozwala na ich zakwalifikowanie do sektora bankowego. Pomimo szczególnej pozycji banków w systemie finansowym, zarówno pod względem systemu gwarancji depozytów czy wysokiego stopnia profesjonalizmu, coraz silniejszą grupę stanowią podmioty zaliczane do sektora pozabankowego, w tym przede wszystkim instytucje pożyczkowe. Poniższy artykuł, poprzez charakteryzację specyfiki sektora oraz grup partycypujących $\mathrm{w}$ transakcjach realizowanych $\mathrm{w}$ jego obszarze, przedstawia prawną analizę w zakresie ustawowych przesłanek warunkujących legalność i uczciwość działalności instytucji pożyczkowych. Wielopłaszczyznowe ujęcie problematyki realizuje nadto główny cel opracowania, którego odpowiednie zrozumienie sprzyja kształtowaniu świadomości prawnej w zakresie materii stosunków zawieranych z omawianą kategorią pożyczkodawców.

Slowa kluczowe: sektor pozabankowy, kredyty konsumenckie, instytucje pożyczkowe, instytucje finansowe, ograniczenia normatywne. 


\section{WSTĘP}

Istotnym ogniwem $\mathrm{w}$ procesie analizy prawnej i próbie usystematyzowania społeczno-gospodarczych determinantów rozwoju sektora pozabankowych kredytów konsumenckich jest funkcjonalne ujęcie zjawiska potrzeb społecznych jako zasadniczego czynnika stymulującego zjawiska gospodarcze ${ }^{1}$. Odpowiednie wyłożenie problematyki stanowiącej istotę niniejszego opracowania sprowadza się nadto do konkretyzacji przesłanek oddziałujących na wskaźnik wzrostu w zakresie liczbowego zestawienia podmiotów prowadzących działalność o określonym przedmiocie. Rynek - choć ze względu na swoją specyfikę - oparty na mechanizmach zmierzających do potęgowania zysków, będąc w przyjętym kontekście zespołem rozwiązań umożliwiających urzeczywistnienie indywidualnych aspiracji zarobkowych, zdaje się także pośrednio (nie stanowiąc jego zasadniczego celu) wpływać na dobrobyt grupy konsumentów partycypujących w określonych transakcjach ${ }^{2}$.

Jednym z wyraźnie zauważalnych trendów występujących w branży finansowej jest rozwój sektora instytucji pożyczkowych. Płynność finansowa postrzegana w kategoriach stabilizatora stopy życiowej jednostek odgrywa niebagatelną rolę w kształtowaniu popytu na działalność przedsiębiorców w zakresie usług pożyczkowych, co stanowi zrozumiałą odpowiedź na zainteresowanie społeczeństwa krótkoterminowymi zobowiązaniami na niewielkie kwoty oraz długoterminowymi pożyczkami wieloratalnymi. Wprawdzie, powyższy przedmiot działalności stanowi przede wszystkim domenę banków, jednak sektor pożyczek pozabankowych rozwija się niezwykle dynamicznie, będąc alternatywą dla klientów dążących do pozyskania kapitału pieniężnego. Banki - ze względu na konieczność ochrony wartości deponowanych środków - niechętnie angażują się w tego rodzaju działalność, odstępując w konsekwencji od grup niedochodowych klientów ${ }^{3}$. Okoliczności te z powodzeniem wykorzystują firmy pożyczkowe, które stosując uproszczoną procedurę zaciągania zobowiązań umożliwiają uzyskanie pożyczki gotówkowej

${ }^{1}$ Powyższe rozważania należałoby także odnieść do zjawiska konsumpcji stanowiącego de facto efekt sprzężenia zwrotnego postępu gospodarczego tj. będąc nie tylko biernym rezultatem wzrostu koniunktury, ale przede wszystkim czynnikiem napędzającym konkretne sektory gospodarki.

2 Teoria tzw. niewidzialnej ręki rynku (invisible hand). Metafora oznacza motywację uczestników rynku do zaspokojenia własnych potrzeb kierując się wyłącznie indywidulanym interesem, czego efektem ubocznym są korzyści osiągane przez konsumentów. Równocześnie z dążeniami zarobkowymi potentatów rynkowych do maksymalizacji zysków, zauważalny jest bowiem wzrost dobrobytu społecznego przejawiającego się w napływie np. aktywów lub dóbr. A. Smith, Badania nad natura i przyczynami bogactwa narodów, wyd. 2, Warszawa, 2018.

3 Z reguły, w celu zapewnienia bezpieczeństwa powierzonych środków oraz pewności ich odzyskania, warunki zaciągania zobowiązań w bankach nakładają obowiązek spełnienia określonych wymogów, które uzależnione są m.in. od płynności finansowej wyznaczającej zdolność kredytową klienta, będącą jednym z najważniejszych czynników, który banki uwzględniają przy podejmowaniu decyzji o udzieleniu kredytu lub pożyczki. 
przez osoby nie mogące otrzymać finansowania w bankach oraz innych instytucjach finansowych.

Oparcie działalności instytucji pożyczkowych - z punktu widzenia konsumenta - na prostocie kontraktowania wiąże się jednak z ryzykiem odnoszącym się wprost do ceny pieniądza, który nierzadko znacząco przewyższał cenę pieniądza bankowego. Wysokie koszty kredytów konsumenckich udzielanych przez omawianą grupę stały się przyczyną ich negatywnego odbioru, co - w standardach wolnego rynku - stwarza realne zagrożenie wyeliminowania przedsiębiorców pożyczkowych z obrotu, stopniowo prowadząc do marginalizacji przedmiotowego sektora (szczególnie wrażliwego na wahania opinii publicznej). Sukcesywnie zwiększane standardy weryfikacji i bezpieczeństwa przekładają się jednak bezpośrednio na sytuację konsumentów, zaś normatywne ograniczenia podejmowania i prowadzenia działalności przez instytucje pożyczkowe zwiększają stopień profesjonalizmu wśród przedsiębiorców.

\section{SEGMENTACJA RYNKU INSTYTUCJI POŻYCZKOWYCH}

Sformułowanie odpowiednich wniosków dotyczących działalności instytucji pożyczkowych uzależnione jest m.in. od wskazania wariacji stosowanych modeli biznesowych tj. segmentów, w ramach których odbywa się świadczenie właściwych usług pożyczkowych. Elementem przesądzającym o ich poprawnym zakwalifikowaniu jest obsługa klienta jako faktor determinujący przebieg procedury udzielenia pożyczki, sposób oraz miejsce zawierania przedmiotowych umów czy wreszcie precyzującego kryteria umożliwiające przeprowadzenie weryfikacji potencjalnego klienta np. w oparciu o jego warunki życiowe. Na podstawie przyjętego kryterium można wyróżnić trzy zasadnicze segmenty odpowiadające podmiotom działającym na rynku':

- segment A - obsługa offline, tj. obsługa domowa,

- segment B - obsługa w oddziale,

- segment $\mathrm{C}$ - obsługa online.

Choć przyjęte rozróżnienie zdaje się być zagadnieniem niewymagającym wnikliwej analizy - głównie za sprawą łatwości zakwalifikowania danego rodzaju działalności do właściwego segmentu - zagadnieniem wartym przybliżenia są formy zaciągania pożyczek w zależności od segmentu. Pożyczkodawca ubiegający się o przyznanie finansowania w instytucji z segmentu A może uczynić to za pośrednictwem formularza online, rozmowy telefonicznej lub kontaktu poprzez wiadomość tekstową. Zbliżony model kontaktu obowiązuje w przypadku segmentu B, w którym możliwa jest także bezpośrednia wizyta w oddziale instytucji - pożyczkobiorca

\footnotetext{
4 Raport PwC Polska Sp. z o.o., Rynek firm pożyczkowych w Polsce, 2013.
} 
zobowiązany jest jednak do dostarczenia kompletu dokumentacji niezbędnej do przeprowadzenia weryfikacji. Komunikacja z klientem wyrażającym wolę pozyskania finansowania za pośrednictwem strony internetowej pożyczkodawcy nie wymaga natomiast szczegółowego omówienia - to najczęściej tzw. pożyczki chwilówki ${ }^{5}$. Przedstawienie katalogu form komunikacji, bardziej właściwe dla raportu analitycznego, nie jest jednak pozbawione sensu na gruncie niniejszego opracowania. Normatywne ujęcie tak prowadzonej działalności nakłada swoisty rygor prawny, który - w kontekście braku nadzoru nad instytucjami pożyczkowymi sprawowanego przez Komisję Nadzoru Finansowego - stanowi narzędzie zabezpieczające przez potencjalnymi nadużyciami.

Segmentacja nie jest jednak jedynym kryterium służącym za podstawę do wyłonienia podstawowych kategorii instytucji pożyczkowych. Szczególną uwagę należałoby zwrócić na problematykę okresu finansowania, który w znacznym stopniu rzutuje na wysokość ostatecznych kosztów ponoszonych przez pożyczkobiorców. Najprostszym i zdaje się także wystarczającym zobrazowaniem omawianej zależności są koszty ponoszone z tytułu oprocentowania oraz prowizji, które wzrastają wprost proporcjonalnie do okresu trwania zobowiązania.

\section{SEKTOR POŻYCZKOWY - TENDENCJE ROZWOJOWE}

Przeprowadziwszy analizę społecznych przesłanek dynamizujących rozkwit działalności instytucji pożyczkowych, ważnym etapem zmierzającym do kompleksowego ujęcia zasięgu sektora pozabankowego jest odniesienie się do wskaźników stricte gospodarczych. Pomimo iż, rozwój sektora bankowego jest przede wszystkim zależny od tempa wzrostu gospodarczego jako czynnika w znacznym stopniu wpływającego na dobrobyt docelowej grupy konsumentów, rozkwit rynku usług pożyczkowych w Polsce stanowi - paradoksalnie - konsekwencję globalnego kryzysu z 2008 roku. Liczna grupa konsumentów utraciła wówczas płynność finansową, zaś wzrost stopy bezrobocia oraz recesja skutecznie doprowadziły do wyparcia tej grupy poza ofertę kredytową dostępną na rynku bankowym. I chociaż wymienione zjawiska sugerują jednoznacznie negatywne konsekwencje z nich wynikające, doprowadziły one w ostateczności do wzmożonego zainteresowania konsumentów usługami świadczonymi w ramach sektora pozabankowego, którzy poszukiwali w nim źródła finansowania indywidualnych potrzeb konsumpcyjnych ${ }^{6}$. Segment

5 Ibidem.

6 Andrzej Bień, Łukasz Gębski, Raport na temat ryzyka kredytowanego oraz metod jego zabezpieczania stosowanych przez niebankowe instytucje finansowe działajace na polskim rynku, Warszawa 2017, Legalis. 
pożyczek na niskie kwoty wyraźnie ewoluuje, zaś funkcjonujące w jego obszarze instytucje pozabankowe zdają się ogrywać kluczową rolę w koniunkturze rynku.

Zachodzące na rynku procesy, bieżąco monitorowane przez właściwe instytucje, umożliwiły wskazanie wyraźniej tendencji rozwojowej. Systematyczny wzrost wartości pożyczek udzielanych przez instytucje pożyczkowe jest stale zauważalny od 2012 roku (jedynie dwukrotnie zanotowano spadek wartości udzielonych pożyczek tj. lata 2008-2009 oraz 2010-2011). Jednym z okresów, w którym odnotowano zwyżkę jest rok 2016, udzielono wówczas pożyczek o wartości $3741 \mathrm{mln}$ złotych (o 262 mln złotych więcej niż w roku 2015)7. Wartość polskiego rynku pożyczek pozabankowych w 2013 roku wyniosła $0,7 \%$ łącznej wartości zobowiązań przekładającą się na oszacowaną łączną wartość sektora w skali 3-4 mld złotych ${ }^{8}$. Podobne wartości wynikają z ustaleń poczynionych przez Komisję Nadzoru Finansowego, która w ramach przygotowanego w 2013 roku raportu wskazała, iż skala działalności firm pożyczkowych w Polsce wyniosła 3-4 mld złotych ${ }^{9}$.

Niewątpliwe znaczenie sektora pozabankowych usług pożyczkowych widoczne jest także na płaszczyźnie sumy pożyczek udzielonych klientom w 2015 roku, które sięgnęły wartości ok. 5,2 mld złotych. Stanowiło to rezultat zwłaszcza stosowania intensywnych zabiegów marketingowych, rozszerzania oferty oraz rozwoju kanału internetowego ${ }^{10}$. Rozwój rynku firm pożyczkowych w Polsce to także efekt przyjętego przez banki modelu biznesowego oraz stale wzrastającego wśród klientów zainteresowania niskokwotowymi i krótkoterminowymi pożyczkami, które ze względu na większy stopień ryzyka grupy klienckiej oraz wysokie koszty stałe są mało atrakcyjne dla banków, o czym była mowa w poprzednich rozdziałach opracowania.

\section{INSTYTUCJE POŻYCZKOWE - PRZYBLIŻENIE POJĘCIA I RAMY REGULACYJNE}

Szczegółowa regulacja działalności podmiotów zajmujących się udzielaniem kredytów konsumenckich została zawarta w ustawie o kredycie konsumenckim z dnia 12 maja 2011 roku $^{11}$. Należy jednak wskazać - gwoli ścisłości - iż instytucje pożyczkowe, pomimo występującego w ich nazwie sugestywnego członu, również

7 Sektor instytucji pożyczkowych w 2016 roku według raportu KPF. Źródło: https://kpf.pl/ sektor-instytucji-pozyczkowych-w-2016-roku-wedlug-raportu-kpf/ [dostęp: 15.09.2018].

8 Diagnoza społeczna 2013. Warunki i jakość życia Polaków, J. Czapiński, T. Panek (red.), Rada Monitoringu Społecznego, Warszawa, 22 sierpnia 2013 r., s. 75.

9 Raport o sytuacji banków w Polsce 2012, Urząd Komisji Nadzoru Finansowego, Warszawa 2013.

10 NWAI Dom Maklerski, Raport analityczny, Rynek firm pożyczkowych, Warszawa 2016.

11 Ustawa z dnia 12 maja 2011 roku o kredycie konsumenckim (Dz. U. 2011 nr 126, poz. 715 z późn. zm.), dalej jako: KredytKonsU. 
kwalifikują się do powyższej grupy, pojęcie kredytu konsumenckiego jest bowiem pojęciem znaczeniowo szerszym od pożyczki ${ }^{12}$. Definicja pojęcia instytucji pożyczkowej wywodzi się natomiast wprost z art. 5 pkt 2a) KredytKonsU, zgodnie z którym za takową należy uznać podmiot spełniający kumulatywnie dwie przesłanki:

1) Pozytywną: podmiot zawierający z konsumentami umowy kredytu konsumenckiego, niezależnie od ich postaci prawnej, zatem również umowy, które nie są kredytem w klasycznym ujęciu tj. umowy pożyczki.

2) Negatywną: podmiot niebędący bankiem krajowym, zagranicznym ani oddziałem banku zagranicznego, spółdzielczą kasą oszczędnościowo-kredytową ani podmiotem udzielającym kredytów konsumenckich przez odroczenie zapłaty za towary lub usługi.

Dokonanie osobnej regulacji grupy podmiotów uzasadnione jest korelatywnymi właściwościami oraz zależnościami funkcjonalnymi sektora pozabankowych kredytów konsumenckich ze stale wzrastającym zainteresowaniem świadczonymi usługami. KredytKonsU określa ponadto obligatoryjne warunki, które stanowią formalny wyznacznik dla przedsiębiorców zamierzających rozpocząć działalność w charakterze instytucji pożyczkowych ${ }^{13}$. Przepisy dotyczą przede wszystkim przesłanek o charakterze organizacyjnym oraz kapitałowym, ale odnoszą się również do niekaralności osób zasiadających w organach instytucji pożyczkowej lub pełniących funkcję prokurenta. Wprowadzenie normatywnych ograniczeń w podejmowaniu i prowadzeniu działalności zmierza do zagwarantowania minimalnego poziomu stabilności sektora i rzetelnego funkcjonowania instytucji pożyczkowych na rynku konsumenckich usług finansowych ${ }^{14}$.

Katalog minimalnych wymagań, jakie powinny spełniać instytucje pożyczkowe został zawarty w art. 59a KredytKonsU. Zalicza się do nich, w pierwszej kolejności, przesłanki dotyczące struktury organizacyjnej instytucji pożyczkowych oraz ich kapitału zakładowego. W myśl rozwiązań przewidzianych przez ustawodawcę, przedsiębiorca może działać wyłącznie w formie spółki akcyjnej lub spółki z ograniczoną odpowiedzialnością ${ }^{15}$. Spółka powinna także dysponować kapitałem zakładowym w wysokości co najmniej 200000 zł, z jednoczesnym zastrzeżeniem, że kwota może zostać wniesiona wyłącznie jako suma pieniężna ${ }^{16}$. Wykluczone jest natomiast pokrycie kapitału zakładowego w sposób polegający na uzyskaniu środków od osób trzecich pod różnymi tytułami obligacyjnymi np. na podstawie umowy kredytu i pożyczki ${ }^{17}$. Pochodzenie kwoty musi być również w każdym

${ }_{12}$ Art. 3 ust. 2 pkt 1 KredytKonsU.

13 Art. 59a i następne ustawy z dnia 12 maja 2011 roku o kredycie konsumenckim (Dz. U. 2011 nr 126, poz. 715 z późn. zm.).

${ }^{14}$ K. Osajda (red.), Ustawa o kredycie konsumenckim. Komentarz, wyd. 2, 2018, Legalis.

15 Art. 59a ust. 1. KredytKonsU.

${ }_{16}$ Art. 59a ust. 2. KredytKonsU.

17 Art. 59a ust. 3. KredytKonsU. 
przypadku udokumentowane. Określenie wysokości kapitału zakładowego sprzyja wstępnej weryfikacji podmiotów ubiegających się o status instytucji pożyczkowej (w kontekście minimalnych gwarancji rzetelności i stabilności), zaś wskazanie negatywnego katalogu źródeł jego pochodzenia narzuca rygor odpowiedzialności za wnoszone środki. Absurdalnym byłoby przecież udzielanie kredytów konsumenckich ze środków obciążonych innym tytułem zwrotnym. Praktyka sprzyjałaby wówczas destabilizacji sektora oraz znacznemu wzrostowi kosztów udzielanych kredytów, które - ze względu na źródło pierwotnego finansowania - obciążone byłyby dodatkowymi kosztami prowizji oraz świadczeń ubocznych. Przyjęcie takiego rozwiązania prowadziłoby w ostatecznym rozrachunku do sukcesywnego spadku zainteresowania świadczonymi usługami i nierentowności. Zrozumiałym jest zatem, że głównym założeniem wprowadzonych wymagań jest zapewnienie bezpieczeństwa obrotu oraz płynności finansowej spółek, które działając na rzecz indywidualnych interesów konsumentów, chronią de facto interes zbiorowy ${ }^{18}$.

Ustawodawca przewiduje również wymagania w zakresie niekaralności osób mających kierowniczy wpływ na funkcjonowanie spółki tj. członków zarządu, rady nadzorczej, komisji rewizyjnej oraz prokurentów. Przesłanka dotyczy przede wszystkim przestępstw przeciwko obrotowi gospodarczemu i mieniu oraz przestępstw skarbowych, jednak wymóg niekaralności obejmuje także tzw. przestępstwa silne przeciwko obrotowi pieniędzmi i papierami wartościowymi oraz przeciwko wiarygodności dokumentów ${ }^{19}$. Katalog powyższych wymagań determinuje ponadto obowiązki związane $\mathrm{z}$ dokumentami dołączanymi do wniosku o wpis spółki do KRS, zamierzającej podjąć działalność w charakterze instytucji pożyczkowej ${ }^{20}$.

Przedstawione przesłanki znacząco oddziałują na rzetelność działalności prowadzonej przez instytucje pożyczkowe, eliminując zagrożenia związane z niewłaściwym obsadzeniem stanowisk. Wprowadzenie ograniczeń w zakresie struktury organizacyjnej oraz kapitału buduje model dwustronnego zaufania, przekładając się bezpośrednio na efektywne funkcjonowanie sektora pozabankowych usług pożyczkowych ${ }^{21}$.

\footnotetext{
${ }^{18}$ K. Osajda (red.), Ustawa o kredycie konsumenckim (...), op. cit.

19 Art. 59a ust. 4. KredytKonsU.

20 Art. 59a ust. 5. KredytKonsU.

${ }^{21}$ K. Osajda (red.), Ustawa o kredycie konsumenckim (...), op. cit.
} 


\section{ROZPOCZĘCIE DZIAŁALNOŚCI PRZEZ INSTYTUCJĘ POŻYCZKOWĄ - REJESTR INSTYTUCJI POŻYCZKOWYCH}

Dodatkowym zabiegiem legislacyjnym wspierającym prewencyjną funkcję zastosowanej konstrukcji prawnej jest obowiązek ujawniania informacji o działalności instytucji pożyczkowej w rejestrze prowadzonym przez Komisję Nadzoru Finansowego ${ }^{22}$. Przepisy mają $\mathrm{w}$ znacznej mierze charakter publicznoprawny sprzyjając stabilizacji transakcji realizowanych w ramach omawianego sektora, zabezpieczając w gruncie rzeczy interesy konsumentów. Instytucja pożyczkowa może bowiem rozpocząć działalności dopiero po uzyskaniu właściwego wpisu. W tym ujęciu stanowi on nie tylko ogólna informację dotyczącą najistotniejszych kwestii organizacyjnych związanych z funkcjonowaniem podmiotu, ale umożliwia przeprowadzanie weryfikacji wymagań wynikających z art. 59a ust. 1-4 KredytKonsU. Jako nowa i osobna postać rejestru podmiotów gospodarczych została wprowadzona w ustawie z dnia 23 marca 2017 roku o kredycie hipotecznym oraz nadzorze nad pośrednikami kredytu hipotecznego i agentami ${ }^{23}$, która znowelizowała ustawę o kredycie konsumenckim. Istotną cechą podmiotów dotychczas prowadzących pozabankową działalność pożyczkową był brak nadrzędnej kontroli i podlegania formom regulacji i nadzoru. Złożenie wniosku podlega jednorazowej opłacie w wysokości 600 zł, a kolejnym opłatom - w wysokości $200 \mathrm{zl}$ - podlegają wnioski w przedmiocie zmiany wpisu $\mathrm{w}$ rejestrze oraz wykreślenia wpisu $\mathrm{z}$ rejestru ${ }^{24}$. Wnoszone opłaty stanowią ekwiwalent kosztów ponoszonych z tytułu prowadzenia rejestru. Można wyodrębnić dwa skutki, jakie pociąga za sobą dokonanie wpisu:

1) Rozpoczęcie działalności przez instytucję pożyczkową,

2) Możliwość udzielenia przez instytucję pożyczkową kredytów konsumenckich (stanowiąc logiczną konsekwencję poprzedniego).

Chociaż sama procedura rejestracji instytucji pożyczkowej jest maksymalnie uproszczona, do jej skutecznego przeprowadzenia niezbędne jest przedłożenie wraz z wnioskiem katalogu dokumentów, których dołączenie stanowi zrozumiałą konsekwencję obowiązujących ograniczeń normatywnych. Wśród nich można wyróżnićé ${ }^{25}$

- pełnomocnictwo ustanowione do występowania przed Komisją Nadzoru Finansowego w sprawie wniosku o wpis instytucji pożyczkowej do rejestru oraz potwierdzenie uiszczenia opłaty skarbowej od pełnomocnictwa, w przypadku ustanowienia pełnomocnika;

${ }^{22}$ Art. 59aa i n. KredytKonsU.

${ }^{23}$ Dz. U. 2017 poz. 819.

${ }^{24}$ Art. 59ad ust. 1 i 2 KredytKonsU.

${ }^{25}$ Zob. wzór wniosku o rejestrację instytucji pożyczkowej. Dane ze strony internetowej Komisji Nadzoru Finansowego. Źródło: https://www.knf.gov.pl/dla_rynku/posrednictwo/instytucje_pozyczkowe [dostęp: 17.05.2018]. 
- zaświadczenie z Krajowego Rejestru Karnego o niekaralności za przestępstwa, o których mowa w art. 59a ust. 4 KredytKonsU;

- oświadczenie potwierdzające, że wnioskodawca jest instytucją pożyczkową utworzoną z zachowaniem art. 59a ust. 5 KredytKonsU;

- wykaz członków zarządu instytucji pożyczkowej;

- dokumenty potwierdzające spełnienie warunków, o których mowa w art. 59a ust. 1 i 2 KredytKonsU, przez podmiot ubiegający się o wpis od rejestru instytucji pożyczkowych;

- oświadczenie potwierdzające spełnienie warunku, o którym mowa w art. 59a ust. 3 KredytKonsU, przez podmiot ubiegający się o wpis od rejestru instytucji pożyczkowych;

- dowód uiszczenia opłaty za wniosek w pis do rejestru;

- aktualny odpis z Krajowego Rejestru Sądowego.

Wpis ma charakter konstytutywny, stanowiąc przesłankę konieczną do stworzenia nowego stanu prawnego. Rejestr ułatwia ponadto organom publicznym sprawowanie kontroli nad sektorem instytucji pożyczkowych. Aktualnie, działalność i praktyki stosowane przez instytucje pożyczkowe analizuje Urząd Ochrony Konkurencji i Konsumentów, który monitoruje legalność praktyk pod kątem potencjalnych naruszeń na gruncie ustawy o ochronie konkurencji i konsumentów ${ }^{26}$.

\section{NIEZGODNA Z PRAWEM DZIAŁALNOŚĆ INSTYTUCJI POŻYCZKOWEJ}

Zapoznawszy się z katalogiem uwarunkowań o charakterze normatywnym, należałoby w następnej kolejności skupić uwagę na rygorze odpowiedzialności za naruszenie wymogów formalnych przewidzianych przez ustawodawcę. Tę materię reguluje rozdział $5 b$ KredytKonsU, a odpowiedzialność przybiera wówczas postać sankcji karnej - grzywny lub kary pozbawienia wolności, dyscyplinując tym samym analizowaną grupę podmiotów. Komentowane przepisy, a zwłaszcza wynikające z nich kary, podkreślają ponadto powagę działalności instytucji pożyczkowych, które pomimo zaklasyfikowania do sektora prywatnego, w znacznym stopniu wpływają na stabilność i porządek publiczny. Z całą pewnością można stwierdzić zatem, że odniesienie wprost do przepisów karnych dopełnia prewencyjny wymiar obowiązujących regulacji.

Adekwatnie do układu treści przedmiotowej ustawy, kolejno zostaną omówione okoliczności uzasadniające przypisanie odpowiedzialności za stypizowane w akcie czyny. Przepis artykułu 59e KredytKonsU przewiduje karę grzywny do 500000 zł oraz karę pozbawienia wolności do 2 lat za prowadzenie działalności polegającej

${ }^{26}$ Zob. Komunikat prasowy Prezesa Urzędu Ochrony Konkurencji i Konsumentów z dnia 2 marca 2018 roku. Źródło: https://www.uokik.gov.pl/aktualnosci.php?news_id=14092 [dostęp: 10.06.2018]. 
na udzielaniu kredytów pomimo braku spełniania wymogów, o których traktuje art. 59a ustawy. Przesłanki te można podsumować wskazując na zasadnicze elementy omawianego przestępstwa:

1) dochodzi do udzielenia kredytu konsumpcyjnego;

2) kredytodawca nie jest bankiem, spółdzielczą kasą oszczędnościowo-kredytową ani przedsiębiorcą oferującym towary i usługi z odroczonym terminem płatności ceny lub wynagrodzenia;

3) kredytodawca nie spełnia wymagań wskazanych w art. 59a KredytKonsU27.

Powyższe przesłanki należy rozpatrywać rozłącznie - do przypisania odpowiedzialności na podstawie art. 59e KredytKonsU wystarczający jest brak spełnienia któregokolwiek z wymagań zawartych w art. 59a ustawy. W wypadku osób fizycznych odpowiedzialność pociągnie za sobą jedynie brak spełnienia przesłanki z art. 59a ust. 1 KredytKonsU (brak formy sp. z o.o. lub akcyjnej) ${ }^{28}$. Logicznym jest bowiem, że podmioty te nie będą w stanie spełnić wymogów co do formy organizacyjno-prawnej czy minimalnego zakładu kapitałowego, właściwych dla spółek kapitałowych prawa handlowego. Kara grzywny i kara pozbawienia wolności mogą zostać zastosowane jednocześnie, co wskazuje na ich kumulatywny charakter będący niezwykle dotkliwym instrumentem prawnej reakcji. Tę samą odpowiedzialność poniosą także członkowie zarządu lub osoby uprawnione do reprezentacji instytucji pożyczkowej, zwłaszcza prokurenci lub pełnomocnicy.

Następny przepis nawiązuje w swojej istocie do przepisów prawa bankowego, które penalizują niezgodne $\mathrm{z}$ upoważnieniem ujawnianie lub wykorzystanie informacji stanowiących tajemnicę bankową ${ }^{29}$. W tym ujęciu dotyczą one z posłużenia się informacjami w zakresie wykraczającym poza ocenę zdolności kredytowej konsumenta i analizę ryzyka kredytowego ${ }^{30}$. Odpowiedzialność wynikająca z art. 59f KredytKonsU przybiera analogiczną postać jak ta określona w art. 171 ust. 5 PrBank, zaś jej adresatami mogą być wyłącznie osoby fizyczne. Kara grzywny wynosi wówczas do 1000000 zł, a kara pozbawienia wolności może sięgnąć 3 lat (również w tym przypadku sankcje mają charakter kumulatywny).

Działalność instytucji pożyczkowych podlega ponadto nadrzędnej formie kontroli polegającej na gromadzeniu danych dotyczących jej funkcjonowania. Przepis artykułu 59g KredytKonsU penalizuje przypadki braku przekazywania danych przez instytucje pożyczkowe do biur informacji gospodarczej ${ }^{31}$. Karze podlega

${ }^{27}$ K. Osajda (red.), Ustawa o kredycie konsumenckim (...), op. cit.

${ }^{28}$ Ibidem.

29 Zob. art. 105 ust. 4 pkt 4 ustawy z dnia 29 sierpnia 1997 r. - prawo bankowe (Dz. U. 1997 nr 140 poz. 939, z późn. zm.), dalej jako: PrBank.

${ }_{30}$ M. Stanisławska (red.), Ustawa o kredycie konsumenckim. Komentarz, wyd. 1, 2018, C.H. Beck.

${ }_{31}$ Instytucje utworzone na podstawie art. 105 ust. 4 PrBank, których rolą jest gromadzenie, przechowywanie oraz pośredniczenie $\mathrm{w}$ udostępnianiu informacji gospodarczych o określonych podmiotach, w tym m.in. instytucjach pożyczkowych. 
wówczas osoba nieprzekazująca w terminie 7 dni informacji właściwych informa$\mathrm{cji}^{32}$. Odpowiedzialność przybiera postać grzywny do kwoty $30000 \mathrm{zł}$. Regulacja zmierza do zapewnienia bieżącej aktualizacji informacji znajdujących się w bazie danych rejestrów kredytowych. Takie rozwiązanie sprzyja przejrzystości i budowaniu systemu zaufania do podmiotów prowadzących działalność w charakterze instytucji pożyczkowych.

Ostatnim przepisem odnoszącym się do instytucji pożyczkowych jest artykuł 59h KredytKonsU regulujący odpowiedzialność z tytułu działalności bez uprzedniego uzyskania wpisu do rejestru instytucji pożyczkowych. Czyn został stypizowany jako przestępstwo zagrożone karą grzywny do 500000 zł. Wprawdzie, dokonane czynności pozostają ważne i skuteczne, jednak dokonujący ich przedsiębiorca naraża się na sankcje karne, nie wyłączając jednak rozszerzenia odpowiedzialności o kary administracyjne ${ }^{33}$. Przepis wskazuje także na podmiot przestępstwa tj. podmiot zbiorowy (osoba prawna) w postaci instytucji pożyczkowej, którą może być jedynie spółka z o.o. lub akcyjna ${ }^{34}$. Chociaż poglądy dotyczące rozważań komu właściwie należałoby przypisać odpowiedzialność - nie są jednolite, zdaje się, że wątpliwości w tym zakresie rozwiewa konstrukcja przepisu, który wprost odsyła do pojęcia instytucji pożyczkowej. Osoba fizyczna prowadząca działalność pożyczkową podlega bowiem odpowiedzialności karnej na podstawie art. 59e ust. 1 KredytKonsU i brak podstaw do przypisywania jej samodzielnej odpowiedzialności na podstawie interpretowanego przepisu ${ }^{35}$.

${ }^{32}$ Rzecz jasna, mowa o osobach obowiązanych do przekazywania rzeczowych informacji ze względu na zakres czynności realizowanych w ramach działalności instytucji pożyczkowej. Takiej odpowiedzialność może podlegać członek zarządu kredytodawcy, jak również osoba uprawniona do jego reprezentowania (art. 59g ust. 2).

${ }_{33}$ Poza sankcją karną wynikającą z komentowanego przepisu, możliwe są także inne rodzaje odpowiedzialności wynikające z odrębnych przepisów. Działanie instytucji pożyczkowej bez wymaganego wpisu do rejestru może zostać zakwalifikowane jako praktyka naruszająca zbiorowe interesy konsumentów w rozumieniu art. 24 i n. ustawy z dnia 16 lutego 2007 r. o ochronie konkurencji i konsumentów (Dz. U. $2007 \mathrm{nr} 50$ poz. 331, z późn. zm.). W tym rygorze, przedsiębiorca naraża się na sankcje administracyjne określone w art. 26 ustawy. Nadto, w przypadku takiej działalności będzie możliwe zastosowanie sankcji z art. 12 ust. 1 ustawy z dnia 23 sierpnia 2007 r. o przeciwdziałaniu nieuczciwym praktykom rynkowym (Dz. U. 2007 nr 171 poz. 1206, z późn. zm.). Zastosowanie przepisu zaktualizuje się w razie wprowadzenia konsumentów w błąd przez kredytodawcę, który polega na nieuczciwym oparciu działalności na zasadzie domniemania rzetelności przedsiębiorcy i spełnieniu wszystkich wymagań formalnych. W świetle przedstawionych argumentów, należy wskazać także, iż powyższe okoliczności uzasadniałaby dochodzenie unieważnienia umowy kredytu (jednak wyłącznie w drodze żądania konsumenta). Na podstawie K. Osajda (red.), Ustawa o kredycie konsumenckim (...), op. cit.

34 T. Czech, Kredyt konsumencki, komentarz, s. 642, 2017, Wolters Kluwer.

${ }^{35}$ Ibidem. 


\section{INSTYTUCJA POŻYCZKOWA JAKO PODATNIK PODATKU OD NIEKTÓRYCH INSTYTUCJI FINANSOWYCH}

Spektrum stosowanych rozwiązań normatywnych wyznaczających kryteria kwalifikacji określonych przedsiębiorców jako instytucji pożyczkowych aktualizuje dodatkowo podatkowy aspekt ich działalności. Objęcie sektora pozabankowych kredytów konsumenckich tzw. podatkiem bankowym ${ }^{36}$, wzbudzającym dotychczas skojarzenia związane przede wszystkim z sektorem bankowym, potwierdza znaczenie omawianej grupy pożyczkodawców w praktyce profesjonalnego obrotu gospodarczego. Rozszerzenie katalogu podatników o instytucje pożyczkowe rodzi zasadniczo konsekwencje ekonomiczne. Niczym zaskakującym jest bowiem stwierdzenie, iż w perspektywie zwiększającej się liczby instytucji pożyczkowych oraz wzrastającego zainteresowania świadczonymi przez nie usługami, prawodawca dostrzegł potencjalne wpływy zasilające budżet z rodzajowych podatków. Rzeczowe rozszerzenie miało w założeniu ustawodawcy doprowadzić nadto do równości podmiotów uczestniczących w runku consumer finance, co jednak zdaje się być nieco idealistyczną formą uzasadnienia wprowadzonych zmian ${ }^{37}$. Rolę odgrywa ponadto kwestia rzeczywistej selekcji, która przyczynia się do realizacji celu weryfikacyjnego polegającego na wyłonieniu grupy najbardziej dochodowych przedsiębiorców pożyczkowych. Pomimo iż, przedsiębiorcy rozpoczynający określoną działalność dążą, w zamiarze osiągnięcia poziomu rentowności, do maksymalizacji obrotów, nie w każdych okolicznościach działalność pożyczkowa w rozumieniu KredytKonsU będzie stanowić podstawę opodatkowania, uzależnioną de facto od czynników finansowych konkretyzujących przesłanki ustawowe.

Materię opodatkowania analizowanej grupy reguluje ustawa o podatku od niektórych instytucji finansowych ${ }^{38}$, która wymieniając podatników w sposób enumeratywny, precyzuje przesłanki warunkujące powstanie obowiązku odprowadzenia daniny. Ustawodawca, słusznie uwzględniając różnorodność przedmiotowego sektora, nie wprowadził bezwzględnej podstawy opodatkowania rozumianej jako każdorazowe osiągnięcie bilansu dodatniego przez kredytodawcę. Zgodnie z treścią ustawy podstawą opodatkowania jest nadwyżka sumy wartości aktywów podatnika, wynikająca z zestawienia obrotów i sald, ustalona na ostatni dzień miesiąca

${ }^{36}$ Nazwa daniny sugeruje wyłącznie dominującą grupę podmiotów nią objętą tj. banki, nie odgrywa zaś roli w zakresie właściwej kwalifikacji konkretnych podmiotów jako podatników.

${ }^{37}$ Użyte sformułowanie dotyczy faktycznej dysproporcji występującej między bankami a instytucjami pożyczkowymi, z oczywistą przewagą na rzecz pierwszej grupy ogrywającej szczególną rolę w systemie finansowym oraz dysponującej szczególnymi przywilejami. I choć pierwotny zamiar ujednolicenia rynku potrzeb konsumenckich poprzez rodzajowy podatek zdawał się ideą co najmniej sprawiedliwą, doprowadził w konsekwencji do pogłębienia dysproporcji.

${ }^{38}$ Ustawa z dnia 15 stycznia 2016 r. o podatku od niektórych instytucji finansowych (Dz. U. 2016 poz. 68 , z późn. zm.) dalej jako: InstFinU. 
na postawie zapisów na kontach księgi głównej, ponad kwotę $200 \mathrm{ml}$ złotych $^{39}$. To właśnie ze względu na próg kwotowy obciążenie fiskalne nie dotyczy wszystkich podmiotów, a wyłącznie liderów rynkowych. Adekwatnie do danych opublikowanych w 2016 roku, podatkiem zostały objęte zaledwie cztery podmioty: Provident, Profi Credit, Vivus i Everest Finanse ${ }^{40}$. Podatek wynosi $0,366 \%$ podstawy opodatkowania miesięcznie ${ }^{41}$.

Poza oczywistym przedmiotem działalności instytucji pożyczkowych tj. udzielaniem finansowania $\mathrm{w}$ postaci powierzenia środków pieniężnych pod tytułem zwrotnym, za takowe instytucje - zgodnie z poglądem wyrażonym w komunikacie Ministerstwa Finansów - mogą zostać uznani, pod pewnymi warunkami, także przedsiębiorcy udzielający konsumentom innych form finansowania, różnych od umowy pożyczki, przykładowo ${ }^{42}$ :

- Przedsiębiorca odraczający konsumentowi termin świadczenia pieniężnego, jeżeli konsument jest zobowiązany do poniesienia jakichkolwiek kosztów związanych z odroczeniem spełnienia świadczenia.

Chociaż wspomniana warunkowość, w powyższym sensie, zdaje się być sygnalizacją jedynie innych istotnych przesłanek determinujących dokonanie poprawnej kwalifikacji prawnej określonych podmiotów jako podatników w rozumieniu InstFinU, można przyjąć, iż nie jest w zupełności stwierdzeniem klarownym, które wymaga sprecyzowania. Funkcjonalne ujęcie problematyki działalności instytucji pożyczkowych stwarza konieczność przeprowadzania wielopłaszczyznowej analizy, której podstawą będzie ustawa o kredycie konsumenckim. Wątpliwości w tym zakresie pojawiają się już na etapie próby zdefiniowania instytucji pożyczkowej i ustalenia znaczenia pojęcia kredytu konsumenckiego. Jak wynika bowiem z wyłączenia zawartego w art. 5 pst 2a lit. c) KredytKonsU, jeżeli określony podmiot udzielałby kredytów konsumenckich w postaci odroczenia zapłaty ceny lub wynagrodzenia za zakup oferowanych przez niego towarów i usług, nie zostałby on uznany za instytucję pożyczkową. Wprawdzie, art. 3 ust. 2 pkt 3 ustawy statuuje, że jeżeli w ramach swojej działalności przedsiębiorca odracza konsumentowi termin spełnienia świadczenia pieniężnego, tylko wówczas stanowi to przykład udzielenia kredytu konsumenckiego, gdy konsument jest zobowiązany w zamian do poniesienia jakichkolwiek kosztów. Pomimo jednak, że taki przedsiębiorca zostanie w istocie zakwalifikowany do grupy udzielającej kredytu konsumpcyjnego, będzie podlegał wyłączeniu z katalogu instytucji pożyczkowych, a tym samym nie

${ }^{39}$ Art. 5 ust. 3 InstFinU.

${ }^{40}$ NWAI Dom Maklerski, Raport analityczny... op. cit.

${ }^{41}$ Art. 7 InstFinU.

42 Źródło: https://www.mf.gov.pl/ministerstwo-finansow/wiadomosci/komunikaty/-/asset_publisher/6Wwm/content/podatek-od-niektorych-instytucji-finansowych-\%E2\%80\%93-pojecie-\%E2\%80\%9Einstytucji-pozyczkowej\%E2\%80\%9D/pop_up?_101_INSTANCE_6Wwm viewMode=print 
będzie on podatnikiem podatku od niektórych instytucji finansowych. Niemniej, należy wyraźnie zauważyć, iż brak poniesienia przez konsumenta takich kosztów w zamian za odroczenie należnego od niego świadczenia pieniężnego nie jest wymogiem, aby wyłączyć kredytodawcę z grona instytucji pożyczkowych. Taki warunek nie został bowiem zastrzeżony w art. 5 pkt 2a lit. c) KredytKonsU. W tym ujęciu ważne jest również, co wynika wprost $\mathrm{z}$ art. 3 ust. 2 pst 3 rzeczowej ustawy, iż jeżeli przedsiębiorca zawarłby $z$ konsumentem umowę o odroczeniu terminu spełnienia świadczenia pieniężnego, w zamian za co konsument nie byłby zobowiązany do poniesienia dodatkowych kosztów, wówczas taka umowa nie mogłaby zostać uznana za umowę kredytu konsumenckiego. Skoro przepis art. 5 pkt 2a lit. c) ustawy wyłącza z grona instytucji pożyczkowych podmioty, których działalność polega na udzielaniu kredytów konsumenckich w postaci odroczenia zapłaty ceny lub wynagrodzenia na zakup oferowanych przez nich towarów i usług, to mowa przede wszystkim o sytuacjach, gdy odroczenie związane byłoby z poniesieniem przez konsumenta jakiegokolwiek kosztu. W przypadku braku takiego kosztu po stronie konsumenta, odroczenie zapłaty ceny lub rozłożenie jej na raty nie stanowiłoby udzielenia przez przedsiębiorcę kredytu konsumenckiego, a właśnie ten termin został użyty w art. 5 pkt 2a lit. c) KredytKonsU ${ }^{43}$.

\section{CAŁKOWITY KOSZT KREDYTU KONSUMENCKIEGO}

Działalność instytucji pożyczkowych, choć podlegająca szczególnym formom kontroli i regulowana szczegółowymi wymogami o charakterze normatywnym, stanowi przede wszystkim działalność gospodarczą, której zasadniczym celem jest osiągnięcie zysku. W tym kontekście, sprawowana kontrola nad analizowanym sektorem pożyczek konsumenckich, umożliwiła zaobserwowanie nadużyć wynikających z rozbieżnych interesów stron stosunków zobowiązaniowych. $Z$ reguły bowiem, interesem przedsiębiorcy jest maksymalizacja zysku, nierzadko kosztem konsumenta, który pożyczając określoną kwotę liczy na relatywnie niewysokie koszty zaciągniętego kredytu. Wcześniej nieuregulowana materia umożliwiała nieograniczone ustalanie wysokości kosztów, które nieraz doprowadzały do wielokrotnego przewyższenia wartości zapożyczanych kwot. Niezwykle ważnym aspektem stało się zatem unormowanie systemu prawnego dotyczącego całkowitego kosztu kredytu konsumenckiego, którego uporządkowanie bez wątpienia zapewniło

${ }_{43}$ Zob. Interpretacja Indywidulana Dyrektora Krajowej Informacji Skarbowej z dnia 29 kwietnia 2018 roku, sygn. 0114-KDIP2-1.4016.1.2018.1.PW.Źródło: http://sip.mf.gov.pl/faces/views/szczegoly/ szczegoly-interpretacji-indywidualnej.xhtml?dokumentId=529992\&poziomDostepu=PUB\&indexAccordionPanel=-1\#tresc [dostęp: 16.05.2018]. 
należyty poziom dbałości o prawidłowe realizowanie uprawnień i obowiązków wynikających ze świadczonych usług.

Na całkowity koszt kredytu konsumenckiego składają się odsetki, których maksymalna wysokość wynosi dwukrotność stopy referencyjnej NBP ${ }^{44}$ powiększonej o 3,5\% oraz pozaodsetkowe koszty kredytu. Reguła wyznaczająca sposób ustalania pozaodsetkowych kosztów została zawarta w ustawie o kredycie konsumenckim, umożliwiając obliczenie kwoty należnej z tytułu umowy kredytu w drodze nieskomplikowanego równania matematycznego ${ }^{45}$. Zgodnie z przyjętymi założeniami, maksymalna wysokość pozaodsetkowych kosztów będzie się równać sumie $25 \%$ całkowitej kwoty kredytu i 30\% zmiennej, uzależnionej od okresu zapożyczenia. Kluczowe dla zabezpieczenia interesu konsumentów było także określenie górnego limitu wszystkich pozaodsetkowych opłat, które de lege lata nie mogą przekroczyć $100 \%$ całkowitej kwoty kredytu. Stanowi to, bez wątpienia, narzędzie niezwykle istotne w zwalczaniu nieuczciwych praktyk i zapobieganiu potencjalnym nadużyciom. Stanowisko w tym zakresie zajął ponadto Urząd Ochrony Konkurencji i Konsumentów w komunikacie prasowym z dnia 8 marca 2016 roku, którego treść przybliża problematykę naruszenia zbiorowych interesów konsumentów przez instytucje pożyczkowe oraz zawiera katalog wskazówek mogących usprawnić proces decyzyjny osób poszukujących źródła finansowania od omawianej grupy podmiotów ${ }^{46}$.

\section{PODSUMOWANIE}

Opracowanie katalogu instrumentów prawnych determinujących legalność funkcjonowania instytucji pożyczkowych doprowadziło do unifikacji standardów w zakresie świadczonych usług. Wynikające ex lege wymogi niezbędne do rozpoczęcia działalności oraz szczególne formy kontroli i weryfikacji zwiększyły stopień profesjonalizmu przedsiębiorców, zaś unormowanie reguł umożliwiających ustalenie ostatecznych kosztów kredytu ukształtowało model społecznego zaufania jako elementarnego czynnika implikującego zrównoważony rozwój sektora. Stale wzrastająca konsumpcja, a także specyfika wolnego rynku pozwoliły zaobserwować zjawisko współzależności przedsiębiorców pożyczkowych i konsumentów, którzy funkcjonalnie ze sobą powiązani kreują popyt i podaż na przedmiotowe usługi. Postępująca cyfryzacja, wzrastająca świadomość oraz oczekiwania społeczeństwa

${ }_{44}$ Zob. podstawowe stopy procentowe NBP. Źródło: https://www.nbp.pl/home.aspx?f=/dzienne/ stopy.htm [dostęp 20.06.2018].

${ }_{45}$ Art. 36a KredytKonsU.

46 Źródło: https://www.uokik.gov.pl/aktualnosci.php?news_id=12253\&print=1\& [dostęp: 22.06.2018]. 
co do jakości świadczonych usług warunkują zmiany omawianego sektora zarówno w kontekście standardów oferowanych konsumentom przez instytucje pożyczkowe, jak i normatywnego uregulowania tak prowadzonej działalności. Założeniem przyświecającym wdrażanym nowelizacjom jest bowiem korekta przyczyn, ze względu na które regulowany rynek nie działa w sposób optymalny. Należy jednak mieć na uwadze dopuszczalny stopień ingerencji prawodawcy, tak aby implementowane regulacje nie przyczyniły się do nadmiernego obciążenia rynku, skutkując powolnym, aczkolwiek niewykluczonym upadkiem podmiotów wchodzących w jego skład. Zdaje się jednak, że idea rygorystycznego usystematyzowania materii pozabankowych kredytów konsumenckich realizuje koncepcję wzmocnienia pozycji prawnej konsumentów, nie naruszając interesu przedsiębiorców, którzy ze względu na oczekiwany profesjonalizm, stanowią obiekt szczególnego zainteresowania organów kontroli uczciwości i legalności stosowanych praktyk rynkowych. Pomimo że, wdrażane zmiany stanowią zwykle efekt następczej reakcji prawnej na wcześniejsze nadużycia, można stwierdzić, że w omawianym zakresie rynek consumer finance, w tym przede wszystkim działalność instytucji pożyczkowych, zapewnia stabilność i przejrzystość sektora pozabankowych kredytów konsumenckich jako stale ewoluującego centrum usług finansowych.

\section{BIBLIOGRAFIA}

A. Smith, Badania nad naturą i przyczynami bogactwa narodów, wyd. 2, Warszawa, 2018.

Andrzej Bień, Łukasz Gębski, Raport na temat ryzyka kredytowanego oraz metod jego zabezpieczania stosowanych przez niebankowe instytucje finansowe działajace na polskim rynku, Warszawa 2017, Legalis.

Diagnoza społeczna 2013. Warunki i jakość życia Polaków, J. Czapiński, T. Panek (red.), Rada Monitoringu Społecznego, Warszawa, 22 sierpnia 2013 r., s. 75.

Interpretacja Indywidulana Dyrektora Krajowej Informacji Skarbowej z dnia 29 kwietnia 2018 roku, sygn. 0114-KDIP2-1.4016.1.2018.1.PW. Źródło: http://sip.mf.gov.pl/faces/views/szczegoly/ szczegoly-interpretacji-indywidualnej.xhtml?dokumentId=529992\&poziomDostepu=PUB\&indexAccordionPanel=-1\#tresc

K. Osajda (red.), Ustawa o kredycie konsumenckim. Komentarz, wyd. 2, 2018, Legalis.

Komunikat Ministerstwa Finansów z dnia 8 sierpnia 2016 roku. Źródło: https://www.mf.gov.pl/ ministerstwo-finansow/wiadomosci/komunikaty/-/asset_publisher/6Wwm/content/podatek-odniektorych-instytucji-finansowych-\%E2\%80\%93-pojecie-\%E2\%80\%9Einstytucji-pozyczkowej\%E2\%80\%9D/pop_up?_101_INSTANCE_6Wwm_viewMode=print

Komunikat prasowy Prezesa Urzędu Ochrony Konkurencji i Konsumentów z dnia 2 marca 2018 roku. Źródło: https://www.uokik.gov.pl/aktualnosci.php?news_id=14092

Komunikat prasowy Urzędu Ochrony Konkurencji i Konsumentów z dnia 8 marca 2016 roku. Źródło: https://www.uokik.gov.pl/aktualnosci.php?news_id=12253\&print=1\&

M. Stanisławska (red.), Ustawa o kredycie konsumenckim. Komentarz, wyd. 1, 2018, C.H. Beck.

NWAI Dom Maklerski, Raport analityczny, Rynek firm pożyczkowych, Warszawa 2016.

Podstawowe stopy procentowe NBP. Źródło: https://www.nbp.pl/home.aspx?f=/dzienne/stopy.htm 
Społeczno-gospodarcze determinanty rozwoju pozabankowego sektora kredytów konsumenckich... 25

Raport o sytuacji banków w Polsce 2012, Urząd Komisji Nadzoru Finansowego, Warszawa 2013. Raport PwC Polska Sp. z o.o., Rynek firm pożyczkowych w Polsce, 2013.

Sektor instytucji pożyczkowych w 2016 roku według raportu KPF. Źródło: https://kpf.pl/sektor-instytucji-pozyczkowych-w-2016-roku-wedlug-raportu-kpf/

T. Czech, Kredyt konsumencki, komentarz, s. 642, 2017, Wolters Kluwer.

Ustawa z dnia 12 maja 2011 roku o kredycie konsumenckim (Dz. U. 2011 nr 126, poz. 715 z późn. zm.) Ustawa z dnia 15 stycznia 2016 r. o podatku od niektórych instytucji finansowych (Dz. U. 2016 poz. 68 , z późn. zm.)

Ustawa z dnia 16 lutego 2007 r. o ochronie konkurencji i konsumentów (Dz. U. 2007 nr 50 poz. 331 , z późn. zm.).

Ustawa z dnia 23 marca 2017 roku o kredycie hipotecznym oraz nadzorze nad pośrednikami kredytu hipotecznego i agentami Dz. U. 2017 poz. 819.

Ustawa z dnia 23 sierpnia 2007 r. o przeciwdziałaniu nieuczciwym praktykom rynkowym (Dz. U. 2007 nr 171 poz. 1206, z późn. zm.).

Ustawa z dnia 29 sierpnia 1997 r. - prawo bankowe (Dz. U. 1997 nr 140 poz. 939, z późn. zm.).

Wzór wniosku o rejestrację instytucji pożyczkowej. Dane ze strony internetowej Komisji Nadzoru Finansowego. Źródło: https://www.knf.gov.pl/dla_rynku/posrednictwo/instytucje_pozyczkowe

\section{SUMMARY}

Consumer lending market, although being commonly associated with banks' offer as a predominant group of entities providing services in such area, applies also to other financial institutions, which legal status does not allow them to be classified into the banking sector. Despite banks' significant role in the financial system, both in terms of deposit guarantee scheme and high service standards, non-banking entities, mainly including loan institutions, are increasingly more important in that matter. The following paper, by providing description of the non-banking sector and groups actively participating in transactions carried out in its area, seeks to sort out statutory premises that determine legality and fairness of the loan institutions. Furthermore, multifaceted approach towards the examined issue fulfills the main purpose of the paper, which proper comprehension conduces developing self awareness over legal relationships created with discussed category of lenders.

Keywords: non-bank sector, consumer loan, loan institution, financial institutions, normative constraints. 